\title{
Image Analysis and Flow Cytometric DNA Studies of Benign and Malignant Body Cavity Fluids: Reappraisal of the Role of Current Methods in the Differential Diagnosis of Reactive Versus Malignant Conditions
}

Oscar Lazcano, M.D., Li-Mien Chen, M.D., Cheng Tsai, M.D., Chin-Yang Li, M.D., Jerry A. Katzmann, Ph.D., Thomas J. Sebo, M.D., Ph.D., Teresa K. Kimlinger, B.A., Julie Baker, M.T.(A.S.C.P.)

Department of Laboratory Medicine and Pathology, Mayo Clinic and Mayo Foundation (L-MC, C-YL, JAK, TJS, TKA), Rochester, Minnesota; the Immunocytometrics Laboratory of Forest Park Hospital, Department of Pathology (OL, CT, JB), St. Louis, Missouri; and Visiting Clinician, Division of Hematopathology from the Division of Hematology/Oncology, Department of Medicine, 803 Army General Hospital, Taichung, and National Defense Medical Center (L-MC), Taipei, Taiwan, Republic of China

Cytologic examination of body fluids is commonly performed in the clinical laboratory. Determination of the presence of malignancy may sometimes be difficult. In this study, we prospectively studied 60 body fluids with a panel of antibodies, including MOC-31, epithelial membrane antigen, carcinoembryonic antigen, B72.3, keratin, desmin, and CA125. DNA and S-phase studies were performed both by flow cytometry and image analysis. Thirty-seven fluids were classified as benign and 23 were classified as malignant. The sensitivity of the antibodies for identification of carcinoma in descending order of percentage detection rate were MOC-31 (95\%), epithelial membrane antigen (93\%), B72.3 (84\%), and carcinoembryonic antigen $(80 \%)$. Desmin stained mesothelial cells in all cases. CA-125 gave similar results but was less specific. Flow cytometry detected 14 of 20 malignant fluids and image analysis 17 of 23 by identifying an aneuploid population. Benign reactive mesothelial cells were not aneuploid. Tetraploidy due to reactive mesothelial cells was found in 9 of 37 body fluids. Their S-phase fraction was low (average, $3.2 \%$ ). Tetraploidy in malignant cells was distinguished from the reactive mesothelial cells by high S-phase (average, 25.95). S-phase had some use as a discriminating factor, because no benign reactive cases had more than 17\%. However, 7 of 23 malignant cases had a value below $17 \%$. DNA analysis by image was more sensi-

Copyright (C) 2000 by The United States and Canadian Academy of Pathology, Inc.

VOL. 13, NO. 7, P. 788, 2000 Printed in the U.S.A.

Date of acceptance: January 5, 2000.

Address reprint requests to: Chin-Yang Li, M.D., Department of Laboratory Medicine and Pathology, Mayo Clinic, 200 First Street SW, Rochester, MN 55905. tive and specific than flow. Either may be used when immunocytochemistry is nondiagnostic or cannot be performed.

KEY WORDS: Body cavity fluids, Cytology, DNA ploidy, Flow cytometry, Image analysis, Mesothelial cells.

Mod Pathol 2000;13(7):788-796

The evaluation of body fluid cytology specimens is common in cytology and hematology laboratories. Sometimes, there are problems of interpretation because of the wide cytologic variance in the appearance of mesothelial cells and neoplastic cells. For example, mesothelial cells can appear as small clusters of medium-sized cells with basophilic cytoplasm and nondescript cytologic features or as large pleomorphic cells with several nuclei and mitoses (1). The most common differential diagnosis is to determine whether atypical cells that are present in a body fluid cytology sample are reactive mesothelial cells or malignant cells (carcinoma, malignant mesothelioma, others). Several recent reviews have considered the use of immunocytochemical markers for detecting carcinoma in fluids, with antibodies such as Ber-EP4, Leu-M1, epithelial membrane antigen (EMA), B72.3, carcinoembryonic antigen (CEA), and MOC-31 (2-12). However, few antibodies are commercially available for identifying mesothelial cells. Two of these antibodies are desmin $(4,13-15)$ and CA-125 $(16,17)$. Another tool that has been used successfully to identify neoplastic cells is DNA ploidy analysis. Although some authors have proposed the use of this method in assessing body fluids for neoplastic cells (2, 18-28), 
others have found it to be of no or limited value (29-31).

The purpose of the present study was to determine prospectively the role of image and flow DNA ploidy in analyzing body fluids to distinguish between benign effusions and malignant ones. The study correlated morphology and immunocytochemistry with DNA ploidy analysis using two techniques, image analysis and flow cytometry. Results obtained by image analysis were compared with those obtained by flow cytometry at two different institutions. The results of DNA ploidy and S-phase were compared with cytology- and/or biopsyproven cases.

\section{MATERIALS AND METHODS}

A prospective study was conducted on body fluid samples (pleural, peritoneal, or pericardial effusions with atypical cells) from 60 patients evaluated from March 1994 to November 1996. The studies included morphologic examination of Wright- and Papanicolaou-stained specimens, immunocytochemistry, and DNA and S-phase studies by both image analysis and flow cytometry. Fluids were divided into benign or malignant categories on the basis of morphology, results of immunocytochemistry, biopsy findings, and clinical follow-up and outcome. Benign cases were those in which no malignancy was found in the fluids by cytology, biopsy, or immunocytochemistry. These patients were alive in June 1998 or had died of unrelated causes. Malignant cases were those in which malignant cells were found in the fluid by cytology, biopsy, or immunocytochemistry. These patients died or demonstrated obvious disease in subsequent follow-up. Of the 60 cases, 37 were classified as benign and 23 were classified as malignant.

\section{Immunocytochemistry}

Cytospin preparations were prepared from all of the body fluid samples. They were fixed in fresh $4^{\circ} \mathrm{C}$ acetone for $5 \mathrm{~min}$ and air-dried for $1 \mathrm{~h}$ at room temperature before being immunostained (acetone is the fixative of choice and is considered crucial for obtaining adequate staining results). The panel of antibodies used for immunostaining all of the specimens included cytokeratin, desmin, EMA, and MOC-31. In one case, S-100 protein and HMB-45 were also used to confirm the diagnosis of malignant melanoma. Immunostaining was performed at Mayo Medical Laboratories according to the peroxidase-labeled streptavidin-biotin method, with 3-amino-9-ethylcarbazole as chromogen. The slides were mounted in a water-soluble mounting medium (3-5).

One set of slides was sent to another study laboratory (Deaconess Immunocytometrics Laboratory, St. Louis, MO), and a complementary panel of antibodies that included desmin, CA-125, CEA, and B72.3 were used for peroxidase and antiperoxidase immunostaining with diaminobenzidine as the chromogen. Various titers were used (Table 1). The slides were mounted in synthetic mounting medium. At both institutions, all slides were stained within 1 week after the cytospin preparations were prepared. On all slides, endogenous peroxidase activity was inhibited with $\mathrm{H}_{2} \mathrm{O}_{2}$ plus azide (32).

TABLE 1. Antibodies Used in the Study

\begin{tabular}{|c|c|c|c|c|}
\hline Procedure & Manufacturer & Clone & Titer & Cell Specificity \\
\hline \multicolumn{5}{|c|}{ Immunocytochemistry } \\
\hline Keratin & Boehringer-Mannheim (Indianapolis, IN) & AE1/AE3 & $1: 300$ & $\begin{array}{l}\text { Mesothelial cells } \\
\text { Epithelial cells (carcinoma) }\end{array}$ \\
\hline MOC-31 & Biogenesis (Franklin, MA) & MOC-31 & $1: 25$ & $\begin{array}{l}\text { Epithelial cells (carcinoma) } \\
\text { Young mesothelial cells (rare) }\end{array}$ \\
\hline EMA & Dako (Carpinteria, CA) & EZ9 & $1: 200$ & $\begin{array}{l}\text { Epithelial cells (carcinoma) } \\
\text { Young mesothelial cells } \\
\text { Malignant mesothelioma }\end{array}$ \\
\hline CEA & Dako & Cat \#A115 & $1: 2,000$ & $\begin{array}{l}\text { Malignant epithelial cells (carcinoma) } \\
\text { Granulocytes } \\
\text { Macrophages }\end{array}$ \\
\hline B72.3 & Signet (Dedham, MA) & B72.3 & $1: 30$ & Malignant epithelial cells (carcinoma) \\
\hline Desmin & Dako & DE-R-11 & D-1:200/M-1:75 & $\begin{array}{l}\text { Mesothelial cells } \\
\text { Muscle cells }\end{array}$ \\
\hline CA-125 & Signet & OC125 & $1: 50$ & $\begin{array}{l}\text { Mesothelial cells } \\
\text { Ovarian carcinoma } \\
\text { Other carcinomas (occasional) }\end{array}$ \\
\hline \multicolumn{5}{|l|}{ Flow cytometry } \\
\hline Keratin & Becton-Dickinson (San Jose, CA) & CAM 5.2 & $20 \mu \mathrm{L} / 1$ million cells & $\begin{array}{l}\text { Epithelial cells (carcinoma) } \\
\text { Mesothelial cells }\end{array}$ \\
\hline CD45 (LCA) & Becton-Dickinson & 2DI & $20 \mu \mathrm{L} / 1$ million cells & $\begin{array}{l}\text { Lymphocytes } \\
\text { Macrophages } \\
\text { Granulocytes }\end{array}$ \\
\hline
\end{tabular}

CEA, carcinoembryonic antigen; EMA, epithelial membrane antigen. 
DNA and S-Phase Analysis

DNA and S-phase analysis was performed by two methods: (1) flow cytometry at Mayo Medical Laboratories and (2) image analysis performed at the Immunocytometrics Department at Deaconess Laboratory in St. Louis, Missouri.

\section{Flow cytometry}

DNA analysis was performed on fresh cytology specimens using a FACScan flow cytometer (Becton-Dickinson Immunocytometry Systems, Mountain View, CA) with Lysis II acquisition software and MODfit analysis software (version 5.2, Verity Software House, Topsham, ME). The cell suspension was washed and fixed with $0.003 \%$ lysolecithin in $1 \%$ paraformaldehyde. Cells were stained with fluorescein isothiocyanate-labeled anticytokeratin, CD45, or mouse IgG1 isotype control (Becton Dickinson). The nuclei in each of the three tubes were stained with propidium iodide, using the modified Vindelov procedure. The data were collected, and the cytokeratin-positive population was analyzed and compared with the cytokeratinnegative population. Although the cytokeratin stain does not resolve reactive and malignant cells, it does analytically isolate the cytokeratin-positive cells. In the cases analyzed in this study, there was a 3- to 20-fold enrichment of the cells of interest. DNA ploidy analysis and S-phase fraction were determined for the cytokeratin-positive cell population. At least 10,000 cells were collected, and at least 500 cytokeratin-positive cells were analyzed. Diploidy was determined by the presence of a G0-G1 peak having a DNA index (DI) equal to 1.00 $( \pm 0.005)$. Nondiploidy was considered as the presence of at least one separate tumor G0-G1 peak having a DI outside the diploid range. If the DI equaled $2.00( \pm 0.15)$, then the cells were classified as tetraploid. Nondiploid peaks were classified as aneuploid. If there was no aneuploid cell population, the total S-phase of the cytokeratin-positive cells was used for the S-phase fraction. If there were aneuploid cells and they represented more than $20 \%$ of the cytokeratin-positive cells and had a DI greater than 1.4, then the aneuploid population was used for the S-phase fraction. If the aneuploid population did not fulfill both of these criteria, then the aneuploid S phase was considered unreliable and the total cytokeratin-positive S-phase fraction was used. If there was more than one aneuploid population, the diploid cells were defined as an extra peak and the total S-phase fraction of the aneuploid peaks was used.

\section{Image analysis}

DNA analysis was performed on cytospin preparations using a CAS-200 image analyzer (Becton-
Dickinson, San Jose, CA). Cells were fixed in acetone at Mayo and were postfixed in $10 \%$ neutral buffered formalin before being stained with the Feulgen method. Two slides per specimen were stained with the Feulgen method, using one standard protocol of Feulgen dye incubation after acid hydrolysis (CAS Feulgen stain per protocol, BectonDickinson, package insert). The sample was analyzed with the 3.0 version of quantitative DNA analysis by selecting at least 200 nuclei from the most atypical-appearing epithelioid cells. Lymphocytes were used as a diploid internal control to avoid using epithelial cells that might represent the cells of interest as an internal control. Lymphocytes are routinely used in image analysis whenever a specimen does not contain an adequate number of benign cells of similar nuclear features. No tissue correction is used when assessing histograms, because nuclei in cytologic samples are intact and not truncated (33-35). Results were reported as diploid or aneuploid with S-phase and G2M. The primary peak DI is automatically marked by the instrument software (in tissue correction mode). The left slope is marked with the first column containing tumor cells. The columns to the left of the primary peak are counted, and the right slope is marked an equal number of columns to the right of the primary peak. The secondary peak is twice the primary peak DI \pm 0.1 . The S phase can be estimated by assuming that the cells between the primary peak and the secondary peak all are proliferating and dividing this number by the total number of cells under all markers.

\section{RESULTS}

\section{Patient Characteristics}

The body fluid samples were obtained from 60 patients (32 abdominal samples, 22 chest samples, and 6 pericardial samples). The mean age of the patients was 60 years (range, 21 to 87 years). The youngest patient with a malignant effusion was 42 years old (adenocarcinoma of the lung). The oldest patient with a malignant effusion was 86 years old. The average age of a patient with a malignant effusion was 64 years. Types of primary tumors are summarized in Table 2.

\section{Immunocytochemical Results}

\section{Keratin}

Staining for keratin was positive in all 22 cases of epithelial malignancy and negative in 1 case of melanoma. Keratin was the most sensitive but least specific antibody for carcinoma, because it also stained mesothelial cells that were present in most of the fluid samples. 
TABLE 2. Malignancies Found in Body Fluids

\begin{tabular}{|c|c|c|}
\hline Fluid & Malignancy & $\begin{array}{l}\text { No. of } \\
\text { Cases }\end{array}$ \\
\hline \multirow[t]{7}{*}{ Abdominal (ascites) $(n=10)$} & Pancreas & 3 \\
\hline & Stomach & 2 \\
\hline & Ovary & 1 \\
\hline & Cholangiocarcinoma & 1 \\
\hline & Breast & 1 \\
\hline & Lung & 1 \\
\hline & Unknown & 1 \\
\hline \multirow[t]{5}{*}{ Chest (pleural) $(n=8)$} & Lung & 4 \\
\hline & Breast & 1 \\
\hline & Stomach & 1 \\
\hline & Ovary & 1 \\
\hline & Melanoma & 1 \\
\hline \multirow[t]{4}{*}{ Pericardial $(n=5)$} & Lung & 2 \\
\hline & Ovary & 1 \\
\hline & Breast & 1 \\
\hline & Unknown & 1 \\
\hline \multirow[t]{8}{*}{ Combined ( $n=23$ ) } & Lung & 7 \\
\hline & Ovary & 3 \\
\hline & Breast & 3 \\
\hline & Stomach & 3 \\
\hline & Pancreas & 3 \\
\hline & Cholangiocarcinoma & 1 \\
\hline & Melanoma & 1 \\
\hline & Unknown & 2 \\
\hline
\end{tabular}

\section{EMA}

All 60 samples were stained with EMA, and 21 of the 22 cases of epithelial malignancy stained positive. Mesothelial cells showed occasional weak positivity, except for occasional moderate staining of small clusters of basophilic mesothelial cells that were also positive for desmin. The pattern of staining was membranous and cytoplasmic, with predominantly membrane staining (Fig. 1).

\section{MOC-31}

Fluid samples from 21 benign and 14 carcinoma cases were stained with MOC-31. Of the 14 carcinoma cases, MOC-31 was positive in 13. In the

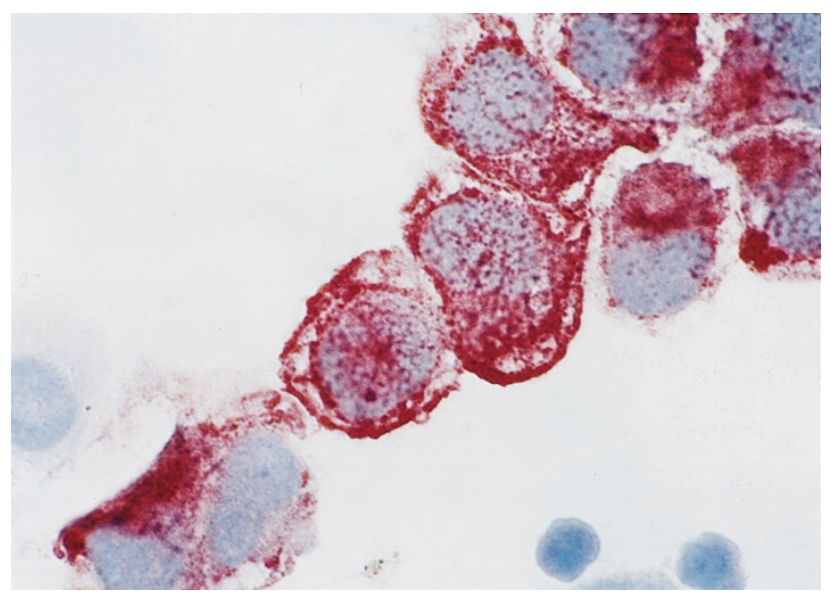

FIGURE 1. Abdominal fluid specimen containing many epithelial membrane antigen (EMA)-positive carcinoma cells and an EMAnegative mesothelial cell in the left lower corner. Note that the staining of tumor cells has both cytoplasmic and membranous patterns (immunoperoxidase stain for EMA, $\times 1000$ ). benign cases, occasional mesothelial cells showed weak positivity. A few cases in which small basophilic mesothelial cells were present showed moderate staining, causing confusion with possible malignant carcinoma cells. However, these basophilic mesothelial cells also stained with desmin. The pattern of staining was membranous and cytoplasmic, with a predominance of membrane staining (Figs. 2 and 3).

\section{CEA}

Fluid samples from 37 benign and 20 carcinoma cases were stained with CEA. Of the 20 carcinoma cases, 16 stained positive. The pattern of staining was mainly cytoplasmic.

\section{$B 72.3$}

Fluid samples from 37 benign and 19 carcinoma cases were stained with B72.3. Of the 19 carcinoma cases, 16 stained positive. The pattern of staining was membranous and cytoplasmic and had a predominant membranous distribution.

\section{Desmin}

All 60 samples were stained with desmin, and the mesothelial cells in all cases stained positively. No reactivity was noted in any of the malignant cells in cases of carcinoma or melanoma. The pattern of staining was cytoplasmic, with a predominantly perinuclear pattern similar to that displayed by keratin (Figs. 3 and 4).

\section{CA-125}

Fifty-nine samples were stained with CA-125. Noteworthy was the presence of strong staining of most, if not all, of the mesothelial cells in the benign and malignant cases. It was positive in the malignant cells of seven cases (three serous carci-

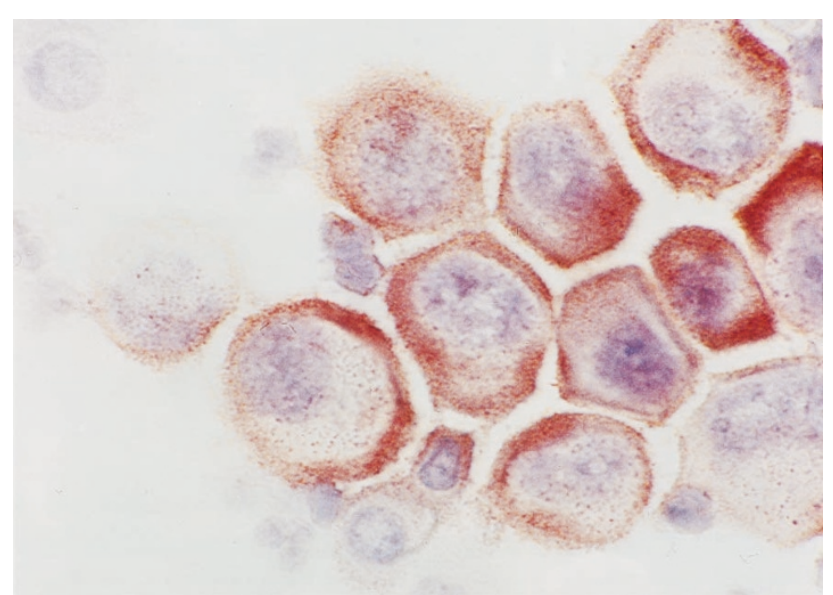

FIGURE 2. Abdominal fluid specimen containing many MOC-31-positive carcinoma cells with predominantly membranous staining. An MOC-31-negative mesothelial cell is present in the upper left corner (immunoperoxidase stain for MOC-31, ×1000). 


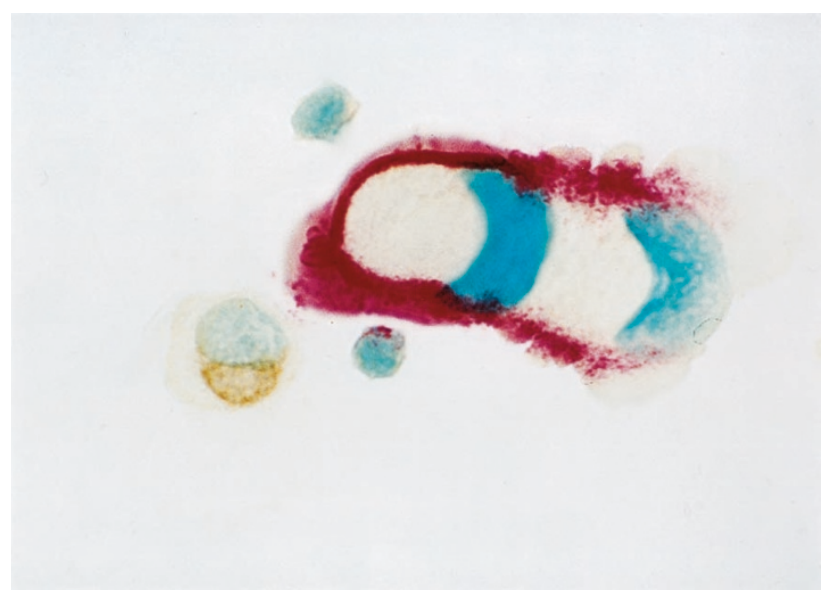

FIGURE 3. A pleural fluid specimen containing MOC-31-positive carcinoma cells (red color, membranous staining) and desmin-positive mesothelial cells (brownish perinuclear staining) (combined immunoalkaline phosphatase stain [red] for MOC-31 and immunoperoxidase stain [brown] for desmin, $\times 1000$ ).

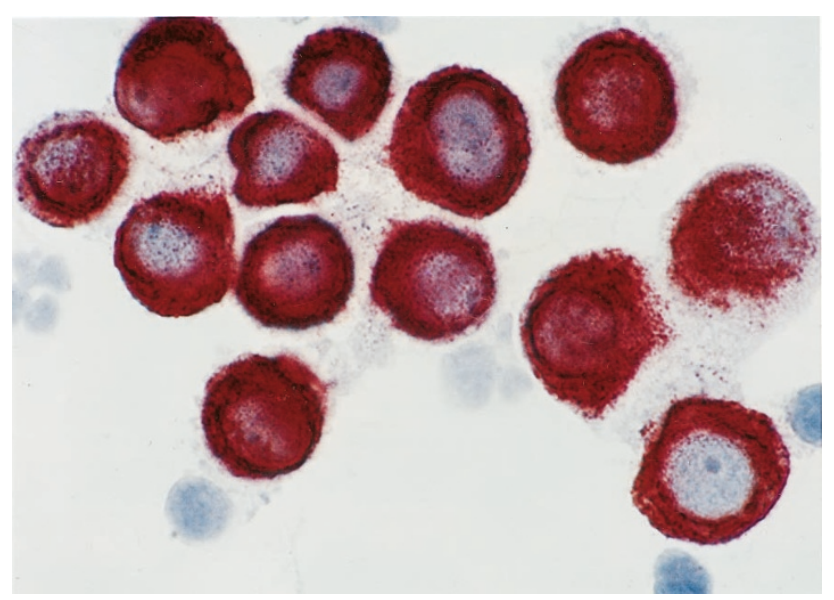

FIGURE 4. A pleural fluid specimen containing many desminpositive mesothelial cells with predominantly a perinuclear cytoplasmic staining pattern (immunoperoxidase stain for desmin, $\times 1000$ ).

nomas of the ovary, one carcinoma of the breast and one of the stomach, one cholangiocarcinoma, and one unknown carcinoma). Tumor cells from the ovary were the only ones to show strong reactivity similar to that of mesothelial cells. The pattern of staining was diffuse cytoplasmic, in contrast to the perinuclear staining displayed by desmin (Fig. 5).

\section{DNA Studies}

Although normal tissues and benign neoplasms may demonstrate aneuploidy and some malignant neoplasms may demonstrate diploidy (36-39), we considered that metastatic malignant tumors would show diploidy less commonly. We divided the fluid samples into four groups: "true positive" were fluid samples with aneuploid malignant cells, "false positive" were benign fluid samples with the presence of aneuploid cells, "true negative" were

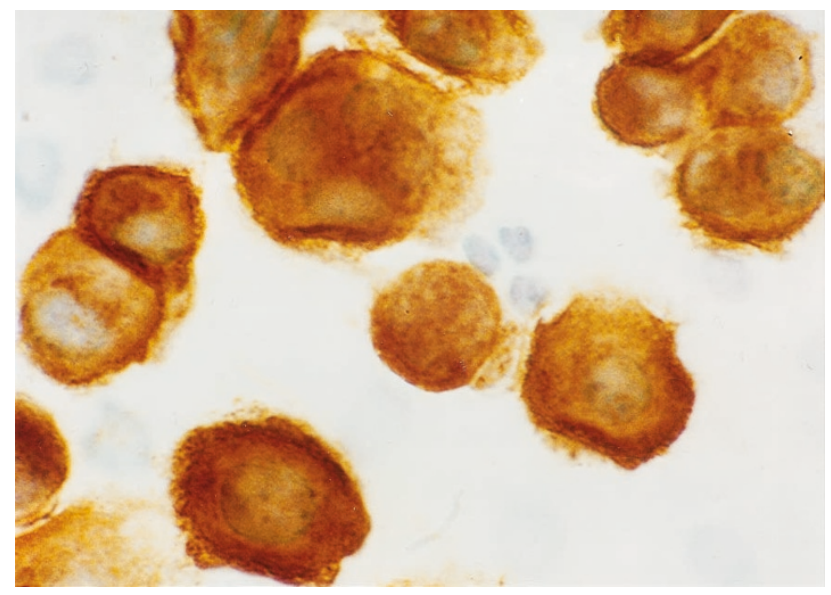

FIGURE 5. A pleural fluid specimen containing many CA-125-positive mesothelial cells with cytoplasmic and predominantly membranous staining (immunoperoxidase stain for CA-125, $\times 1000$ ).

benign fluid samples with diploid cells, and "false negative" were malignant fluid samples with diploid cells.

\section{Flow Cytometry}

Fluid samples from 29 benign and 20 malignant cases were analyzed with flow cytometry (Tables 3 and 4$)$. Of the 20 malignant cases, $14(70 \%)$ were interpreted as aneuploid and $6(30 \%)$ as diploid (false negative). Of the 29 benign cases, 1 was interpreted as aneuploid (false positive). Tetraploidy was found in four malignant cases and in none of the benign cases. The average for the $\mathrm{S}$ phase in 13 malignant cases was $12.7 \%$ (range, 2 to $25 \%$ ) and in the 22 benign cases, $2.9 \%$ (range, 1 to $11 \%$ ). In the four malignant cases demonstrating tetraploidy, the average for the S phase was $15.8 \%$ (range, 9 to $22 \%)$.

\section{Image Analysis}

All fluid samples were subjected to image analysis (Tables 3 and 4). Of the 23 malignant cases, 17 (74\%) were interpreted as aneuploid (true positive). Six malignant cases (26\%) were interpreted as diploid (false negative). None of the 37 benign cases showed aneuploidy (false positive). Among all of the fluid samples, 16 were tetraploid: 7 from malignant cases and 9 from benign cases. The average percentage of cells in area B of the DNA histogram (S-phase fraction) for all of the malignant cases was $20.3 \%$ (range, 7 to $44 \%$ ), compared with the benign fluid, which was $5.4 \%$ (range, 0 to $16 \%$ ). Tetraploidy was found in both benign and malignant fluids: in 7 malignant cases and 9 benign cases. The average for the S-phase fraction in the seven malignant tetraploid cases was $25.9 \%$ (range, 15 to $33 \%$ ) and in the nine benign tetraploid cases, $3.2 \%$ (range, 0 to $12.9 \%)$. 


\begin{tabular}{|c|c|c|c|c|c|}
\hline \multirow{2}{*}{ Method } & \multicolumn{2}{|c|}{ DNA Nondiploid } & \multirow{2}{*}{ DNA Diploid } & \multirow{2}{*}{$\begin{array}{c}\text { Average } \\
(\%)\end{array}$} & \multirow{2}{*}{$\begin{array}{c}\text { Range } \\
(\%)\end{array}$} \\
\hline & Aneuploid & Tetraploid & & & \\
\hline \multicolumn{6}{|l|}{ Flow cytometry } \\
\hline \multicolumn{6}{|l|}{ DNA analysis } \\
\hline \multicolumn{6}{|l|}{ Fluids } \\
\hline Benign $(n=29)$ & 1 & 0 & 28 & & \\
\hline \multirow{2}{*}{\multicolumn{6}{|c|}{$\mathrm{S}$ phase }} \\
\hline & & & & & \\
\hline \multicolumn{6}{|l|}{ Fluids } \\
\hline Benign $(n=22)$ & & & & 2.9 & $1-11$ \\
\hline Malignant $(n=13)$ & & & & 12.7 & $2-25$ \\
\hline Tetraploid $(n=4)$ & & & & 15.8 & $9-22$ \\
\hline \multicolumn{6}{|l|}{ Image analysis } \\
\hline \multicolumn{6}{|l|}{ DNA analysis } \\
\hline \multicolumn{6}{|l|}{ Fluids } \\
\hline Benign $(n=37)$ & 0 & 9 & 28 & & \\
\hline Malignant $(n=23)$ & 10 & 7 & $6^{a}$ & & \\
\hline \multicolumn{6}{|l|}{ S phase } \\
\hline \multicolumn{6}{|l|}{ Fluids } \\
\hline \multicolumn{6}{|l|}{ Benign } \\
\hline Diploid $(n=28)$ & & & & 5.4 & $0-16$ \\
\hline Tetraploid $(n=9)$ & & & & 3.2 & $0-12.9$ \\
\hline Malignant $(n=23)$ & & & & 18.1 & $2-44$ \\
\hline $\operatorname{True}^{b}(n=17)$ & & & & 20.3 & $7-44$ \\
\hline Tetraploid $(n=7)$ & & & & 25.9 & $15-33$ \\
\hline
\end{tabular}

${ }^{a}$ Morphologic or immunohistochemical studies revealed very few malignant cells in five cases. Values obtained are thought to represent background reactive mesothelial cells. One case was operator error and incorrect selection of cells; therefore, no true diploid malignant fluids were found.

${ }^{b}$ Excluding false-negative result.

TABLE 4. Sensitivity of Different Methods in Detection of Malignancies

\begin{tabular}{lcc}
\hline & $\begin{array}{c}\text { Detection } \\
\text { Rate (\%) }\end{array}$ & Positive Cases/Cases Studied \\
\hline Immunocytochemistry & 95 & $21 / 22^{b}$ \\
EMA & 93 & $13 / 14^{b}$ \\
MOC-31 & 84 & $16 / 19^{b}$ \\
B72.3 & 80 & $16 / 20$ \\
CEA & 70 & $14 / 20^{c}$ \\
DNA analysis & 74 & $17 / 23^{d}$ \\
Flow cytometry & & $6 / 13$ \\
Image analysis & 46 & $13 / 23$ \\
S phase (high S-phase & 57 & 13/17 if cases with few \\
$\quad$ value) & 76 & malignant cells excluded \\
Flow cytometry $(\geq 12 \%)^{a}$ & & (false negative) by DNA \\
Image analysis $(\geq 17 \%)^{a}$ & \\
$\quad$ &
\end{tabular}

\section{DISCUSSION}

Mesothelial cells are commonly seen in specimens of body fluids. The finding of atypical "epithelioid" cells is also common. The most common diagnostic dilemma is whether the atypical cells represent reactive mesothelial cells or metastatic carcinoma. In comparison with biopsy specimens, cytology specimens are more difficult to assess because the clinical history is often incomplete. Also, no histologic pattern of growth is present. Accurate diagnosis is critical so that patients can be stratified into the appropriate treatment plan.
The population of mesothelial cells found in body fluids is not homogeneous but consists of cells in various stages of maturation and degeneration. In fact, mesothelial cells may present several different antigenic epitopes as they mature or undergo transformation, as do other cells, such as lymphocytes. They may appear as small groups of cells with basophilic cytoplasm without cytologic atypia or they may appear as large cells and have nuclear atypia. There are even degenerative forms, with vacuolated cytoplasm, that mimic macrophages. Mesothelial cells also may form large clusters and mimic adenocarcinoma (1).

Although many of the cases included in the study showed distinctive cytologic characteristics of either malignant cells or benign mesothelial cells, the cells in 8 of the 23 malignant cases and in 11 of the 37 benign cases showed overlapping cytologic characteristics and the additional ancillary methods were thought necessary to confirm the diagnosis.

\section{Immunocytochemistry}

In the comparison of the five epithelial markers used in our study, MOC-31 was the most sensitive and most specific marker, as reported previously (2, 6). In descending order, the sensitivities of antibodies for identifying epithelial malignancy were EMA, MOC-31, B72.3, and CEA. However, MOC-31 stained more cells than EMA, and CEA stained more cells than B72.3. Keratin was used as a positive control to study immunoreactivity and to verify the epithelial origin of the cells. 
Mesothelial cells are antigenically complex; they consistently stain with desmin and CA-125 and may even stain positively with neuroendocrine markers such as Leu-7 and neuron-specific enolase $(40,41)$. Desmin was the best antibody for selectively staining mesothelial cells, because it consistently stained most of the mesothelial cells in all of the fluid samples tested. CA-125 had a similar spectrum of reactivity but was less specific. Recent studies of adhesion molecules indicated a high level of expression of $\mathrm{N}$-cadherin in mesothelioma and E-cadherin in all pulmonary adenocarcinomas (42, 43). Additional studies to confirm the sensitivity and specificity of $\mathrm{N}$-cadherin as a marker for positive identification of mesothelial cells and mesothelioma may improve our ability to evaluate body fluids immunocytochemically.

\section{DNA and S Phase}

DNA analysis and the S-phase fraction seem to be useful in evaluating body fluids. The best results were obtained with image analysis because it was more sensitive than flow cytometry. Furthermore, the fluid sample was more "accessible" for study and required only a cytospin preparation. Flow cytometry, however, required a fresh specimen. This may be a problem in some laboratories after normal working hours and on weekends and holidays and if the samples need to be sent to a reference laboratory. Image analysis correctly detected 18 of $23(78 \%)$ malignant specimens as aneuploid. We retrospectively investigated the cause of the six false-negative cases. For five of these cases, very few malignant cells were on the slides, and in the sixth case, the cells were present but not abundant. Repeat analysis on this last case did detect the abnormal population. Therefore, we believe that the cause of the false-negative result in at least five cases was due to the presence of very small populations of malignant cells that could not be sampled and, therefore, could not be detected with the image analyzer. The results of the DNA analysis are thought to be the result of background reactive mesothelial cells. This most likely is why the malignant cells were not also detected with flow cytometry.

An important finding was the presence of tetraploidy in benign fluids. This could lead to a suspicion of malignancy and subsequent unnecessary studies or procedures. Tetraploid mesothelial cells were found in 9 of the 37 benign specimens $(24 \%)$ analyzed. This is not surprising because reactive mesothelial cells can have several nuclei and even exhibit mitotic figures. The difference between benign tetraploid mesothelial cells and malignant tetraploid carcinoma cells was the low S-phase fraction of the benign cases (average, 3.2\%). For the malignant cases, the average was $25.9 \%$. It is not clear why these cases were detected only with image analysis, but we believe that it is explained by the selection of more atypical cells during cell selection for image analysis. In flow cytometry, these cells are mixed with many normal populations of mesothelial cells, making it more difficult to detect abnormal DNA ploidy in malignant cells because of the diluting effect. Also, tetraploid cells may be considered as cell clusters or clumps and are excluded from analysis.

Previous studies have reported varying sensitivities for detecting DNA aneuploidy in malignant effusion (18-20), ranging from 63.8 to $68 \%$. Our sensitivity for detecting aneuploid cells was $70 \%$ for flow cytometry and $74 \%$ for image analysis. Clearly, sensitivity depends on the tumor load in a fluid sample. We believe that the sensitivity would be much higher if adequate numbers of tumor cells were in sufficient number to be sampled in the fluid.

By itself, the S phase was a general indication of the proliferative capacity of the cells studied. On image analysis, an S phase of $17 \%$ or more was not seen in any of the benign cases. Therefore, in our laboratory, any value more than $17 \%$ alerts us to the presence of a malignant cell population in the specimen. However, this finding is not very sensitive because 10 of 23 malignant cases had a value of less than $17 \%$. If only the cases with frequent tumor cells are included, it detected 13 of 17 cases. Mesothelial cells infrequently have a high S-phase fraction in reactive conditions (up to $16 \%$ by image analysis), with less variance from the average $(5.4 \%)$. Similar results have been reported previously (26).

On the basis of our results, we believe that DNA and S-phase analysis is useful in the differential diagnosis of effusions with cytologically atypical cells if immunostaining cannot be performed or the results are inconclusive.

If a body fluid contains either atypical cells or cells that are indeterminate for malignancy (e.g., reactive mesothelial cells versus tumor) and the definite cytologic diagnosis of malignancy cannot be made, then the next step, we believe, is to perform immunocytochemistry. If at least two markers are positive, then it is thought that there is sufficient evidence of malignancy. However, the origin of the tumor remains to be determined to establish the appropriate treatment. If both morphologic and immunocytochemical studies have been equivocal or failed to prove malignancy, then cytometric studies that show the presence of aneuploidy and/or a high S phase may be suggestive of malignancy. Cytometric studies themselves cannot determine the origin of tumors; therefore, correlation with other results, history, and clinical follow-up is 
necessary. These results may also serve as prognostic indicators of some tumors.

In our opinion, the use of keratin, MOC-31, EMA/ CEA, and desmin optimizes the classification of body fluids that are suspicious for malignancy. These antibodies constitute a basic screening panel, with other antibodies added as needed for fluid samples that contain malignant cells of nonepithelial origin. DNA and S-phase studies may be backup methods in certain cases. It is most useful when the morphology is suspicious but immunostaining results are inconclusive, especially in cases of nonepithelial malignancy in which routine epithelial markers used were negative. Although aneuploidy does not distinguish between different types of tumors, it indicates malignancy until proved otherwise. Diploidy may be present in samples from malignant cases for several reasons, including insufficient number of malignant cells, diploid metastatic tumors, or true diploid malignant mesotheliomas (21-24). Some examples of known diploid tumors are breast cancer, lymphomas, certain lung tumors, and most small blue-cell tumors. DNA also may be used as a prognostic indicator in malignant mesothelioma $(22,23)$. Furthermore, evaluation of DNA content by image analysis may be useful in cases in which no more fluid sample is available and immunostaining cannot be performed. Previously stained smears (Papanicolaou stain and hematoxylin and eosin) may be destained and then restained with Feulgen dye to determine ploidy and S-phase fraction.

Although some authors have supported the use of cytometric analysis for finding malignant cells in body fluids $(2,18-28)$, others have criticized its use $(29,30)$. We believe that our study proves that it is a very useful tool if used appropriately. It should be used only after morphologic and immunocytochemical studies have not yielded enough information. Useful variables are DNA ploidy and S phase.

In summary, evaluation of body fluids with appropriate immunostains and/or DNA analysis is helpful in distinguishing fluids with malignant cells from those that contain benign reactive mesothelial cells, especially when uncertainty exists because of atypical morphologic characteristics. Although these studies initially require additional expense, they may forestall other, more expensive, and possibly interventional diagnostic studies.

Acknowledgments: The authors thank Sara K. Brackett, Lisa Wilcox, and Jennifer Ivie for their assistance in the preparation of the manuscript.

\section{REFERENCES}

1. Battifora H, McCaughey WTE. Tumors of the serosal membranes. In: Atlas of tumor pathology. 3rd series, Fascicle 15.
Washington DC: Armed Forces Institute of Pathology; 1995. p. 15-97.

2. Chen LM, Lazcano O, Katzmann JA, Kimlinger TK, Li CY. The role of conventional cytology, immunocytochemistry, and flow cytometric DNA ploidy in the evaluation of body cavity fluids: a prospective study of 52 patients. Am J Clin Pathol 1998;109:712-21.

3. Li C-Y, Yam LT, Sun T. Modern modalities for the diagnosis of hematologic neoplasms: color atlas/text. New York: IgakuShoin; 1996. p. 156-7.

4. Li CY, Lazcano-Villareal O, Pierre RV, Yam LT. Immunocytochemical identification of cells in serous effusions. Technical considerations. Am J Clin Pathol 1987;88:696-706.

5. Li CY, Ziesmer SC, Wong YC, Yam LT. Diagnostic accuracy of the immunocytochemical study of body fluids. Acta Cytol 1989;33:667-73.

6. Delahaye M, Hoogsteden HC, Van der Kwast TH. Immunocytochemistry of malignant mesothelioma: OV632 as a marker of malignant mesothelioma. J Pathol 1991;165:13743.

7. Brown RW, Clark GM, Tandon AK, Allred DC. Multiplemarker immunohistochemical phenotypes distinguishing malignant pleural mesothelioma from pulmonary adenocarcinoma. Hum Pathol 1993;24:347-54.

8. Frisman DM, McCarthy WF, Schleiff P, Buckner SB, Nocito JD Jr, O'Leary TJ. Immunocytochemistry in the differential diagnosis of effusions: use of logistic regression to select a panel of antibodies to distinguish adenocarcinomas from mesothelial proliferations. Mod Pathol 1993;6:179-84.

9. Bedrossian CW, Bonsib S, Moran C. Differential diagnosis between mesothelioma and adenocarcinoma: a multimodal approach based on ultrastructure and immunocytochemistry. Semin Diagn Pathol 1992;9:124-40.

10. Skov BG, Lauritzen AF, Hirsch FR, Skov T, Nielsen HW. Differentiation of adenocarcinoma of the lung and malignant mesothelioma: predictive value and reproducibility of immunoreactive antibodies. Histopathology 1994;25:431-7.

11. Joglekar VM, Oliver D, Harris M. The value of anticarcinoembryonic antigen, human milk factor globulin, and antikeratin antibodies in differentiating mesothelioma from lung carcinoma. Br J Ind Med 1991;48:34-7.

12. Wirth PR, Legier J, Wright GL Jr. Immunohistochemical evaluation of seven monoclonal antibodies for differentiation of pleural mesothelioma from lung adenocarcinoma. Cancer 1991;67:655-62.

13. Altmannsberger M, Weber K, Droste R, Osborn M. Desmin is a specific marker for rhabdomyosarcomas of human and rat origin. Am J Pathol 1985;118:85-95.

14. Hurlimann J. Desmin and neural marker expression in mesothelial cells and mesotheliomas. Hum Pathol 1994;25:753-7.

15. Zeng L, Fleury-Feith J, Monnet I, Boutin C, Bignon J, Jaurand MC. Immunocytochemical characterization of cell lines from human malignant mesothelioma: characterization of human mesothelioma cell lines by immunocytochemistry with a panel of monoclonal antibodies. Hum Pathol 1994; 25:227-34.

16. Motoyama T, Watanabe T, Okazaki E, Tanaka N, Watanabe H. Immunohistochemical properties of malignant mesothelioma cells in histologic and cytologic specimens. Acta Cytol 1995;39:164-70.

17. Friedman MT, Gentile P, Tarectecan A, Fuchs A. Malignant mesothelioma: immunochemistry and DNA ploidy analysis as methods to differentiate mesothelioma from benign reactive mesothelioma cell proliferation and adenocarcinoma in pleural and peritoneal effusions. Arch Pathol Lab Med 1996;120:959-66.

18. Joseph MG, Banerjee D, Harris P, Gibson S, McFadden RG. Multiparameter flow cytometric DNA analysis of effusions: a prospective study of 36 cases compared with routine cytol- 
ogy and immunohistochemistry. Mod Pathol 1995;8:686-93.

19. Hedley DW, Philips J, Rugg CA, Taylor IW. Measurement of cellular DNA content as an adjunct to diagnostic cytology in malignant effusions. Eur J Cancer Clin Oncol 1984;20:74952.

20. Rijken A, Dekker A, Taylor S, Hoffman P, Blank M, Krause JR. Diagnostic value of DNA analysis in effusions by flow cytometry and image analysis. A prospective study on 102 patients as compared with cytologic examination. Am J Clin Pathol 1991;95:6-12.

21. Esteban JM, Sheibani K. DNA ploidy analysis of pleural mesotheliomas: its usefulness for their distinction from lung adenocarcinomas. Mod Pathol 1992;5:626-30.

22. Dejmek A, Stromberg C, Wikstrom B, Hjerpe A. Prognostic importance of the DNA ploidy pattern in malignant mesothelioma of the pleura. Anal Quant Cytol Histol 1992;14: 217-21.

23. Isobe H, Sridhar KS, Doria R, Cohen F, Raub WA, Saldana M, et al. Prognostic significance of DNA aneuploidy in diffuse malignant mesothelioma. Cytometry 1995;19:86-91.

24. Huang MS, Tsai MS, Wang TH, Lin MS, Chong IW, Chen KL, et al. Flow cytometric DNA analysis of pleural effusions. Kao Hsiung I Hsueh Ko Hsueh Tsa Chih 1992;8:640-6.

25. Niggli FK, Gray TJ, Raafat F, Stevens MC. Spectrum of peritoneal mesothelioma in childhood: clinical and histopathologic features, including DNA cytometry. Pediatr Hematol Oncol 1994;11:399-408.

26. Huang MS, Tsai MS, Hwang JJ, Wang TH. Comparison of nucleolar organiser regions and DNA flow cytometry in the evaluation of pleural effusion. Thorax 1994;49:1152-6.

27. Pyrhonen S, Laasonen A, Tammilehto L, Rautonen J, Anttila S, Mattson K, et al. Diploid predominance and prognostic significance of S-phase cells in malignant mesothelioma. Eur J Cancer 1991;27:197-200.

28. El-Naggar AK, Ordonez NG, Garnsey L, Batsakis JG. Epithelioid pleural mesotheliomas and pulmonary adenocarcinomas: a comparative DNA flow cytometric study. Hum Pathol 1991;22:972-8.

29. Pinto MM. DNA analysis of malignant effusions. Comparison with cytologic diagnosis and carcinoembryonic antigen content. Anal Quant Cytol Histol 1992;14:222-6.

30. Jones MA, Hitchcox S, D’Ascanio P, Papillo J, Tarraza HM. Flow cytometric DNA analysis versus cytology in the evaluation of peritoneal fluids. Gynecol Oncol 1991;43:226-32.

31. Rodriguez de Castro F, Molero T, Acosta O, Julia-Serda G, Caminero J, Cabrera P, et al. Value of DNA analysis in addi- tion to cytological testing in the diagnosis of malignant pleural effusions. Thorax 1994;49:692-4.

32. Li CY, Ziesmer SC, Lazcano-Villareal O. Use of azide and hydrogen peroxide as an inhibitor for endogenous peroxidase in the immunoperoxidase method. J Histochem Cytochem 1987;35:1457-60.

33. Taylor SR, Titus-Ernstoff L, Stitely S. Central values and variation of measured nuclear DNA content in imprints of normal tissues determined by image analysis. Cytometry 1989;10:382-7.

34. Bacus JW, Bacus JV. A method of correcting DNA ploidy measurements in tissue sections. Mod Pathol 1994;7:652-64.

35. Bacus JW, Bacus JV. Quality control in image cytometry: DNA ploidy. J Cell Biochem 1994;19(Suppl):153-64.

36. Arber DA, Speights VO. Aneuploidy in benign seminal vesicle epithelium: an example of the paradox of ploidy studies. Mod Pathol 1991;4:687-9.

37. Longin A, Fontaniere B, Pinzani V, Catimel G, Souchier C, Clavel M, et al. An image cytometric DNA-analysis in breast neoplasms. Parameters of DNA-aneuploidy and their relationship with conventional prognostic factors. Pathol Res Pract 1992;188:466-72.

38. Schelfhout LJ, Cornelisse CJ, Goslings BM, Hamming JF, Kuipers-Dijkshoorn NJ, van de Velde CJ, et al. Frequency and degree of aneuploidy in benign and malignant thyroid neoplasms. Int J Cancer 1990;45:16-20.

39. Alho A, Skjeldal S, Pettersen EO, Melvik JE, Larsen TE. Aneuploidy in benign tumors and nonneoplastic lesions of musculoskeletal tissues. Cancer 1994;73:1200-5.

40. Mayall FG, Gibbs AR. The histology and immunohistochemistry of small cell mesothelioma. Histopathology 1992;20:4751.

41. Mayall FG, Jasani B, Gibbs AR. Immunohistochemical positivity for neuron-specific enolase and Leu-7 in malignant mesotheliomas. J Pathol 1991;165:325-8.

42. Peralta Soler A, Knudsen KA, Jaurand MC, Johnson KR, Wheelock MJ, Klein-Szanto AJ, et al. The differential expression of $\mathrm{N}$-cadherin and E-cadherin distinguishes pleural mesotheliomas from lung adenocarcinomas. Hum Pathol 1995; 26:1363-9.

43. Han AC, Peralta-Soler A, Knudsen KA, Wheelock MJ, Johnson KR, Salazar H. Differential expression of $N$-cadherin in pleural mesotheliomas and E-cadherin in lung adenocarcinomas in formalin-fixed, paraffin-embedded tissues. Hum Pathol 1997;28:641-5. 